Edunomika - Vol. 02, No. 01 (Pebruari 2018)

\title{
PENINGKATAN PRESTASI BELAJAR BAHASA INDONESIA MATERI MEMAHAMI IKLAN BARIS MELALUI PENERAPAN METODE PROBLEM BASED LEARNING (PBL)PADA SISWA KELAS IX D SMP NEGERI 6 SUKOHARJO SEMESTER I TAHUN PELAJARAN 2017/2018
}

\author{
Tri Indyastuti
}

SMP Negeri 6 Sukoharjo, Jawa Tengah

Email: triindyastuti@gmail.com

\begin{abstract}
Abstrak: Penelitian ini bertujuan untuk meningkatkan prestasi belajar Bahasa Indonesia materi memahami iklan baris pada siswa kelas IX D SMP Negeri 6 Sukoharjo semester I Tahun Pelajaran 2017/2018 melalui penerapan metode Problem Based Learning (PBL). Penelitian ini menggunakan bentuk penelitian tindakan kelas yang dilaksanakan dalam 2 (dua) siklus, dilaksanakan di SMP Negeri 6 Sukoharjo dengan subjek penelitian seluruh siswa kelas IX D SMP Negeri 6 Sukoharjo semester I Tahun Pelajaran 2017/2018 yang berjumlah 22 siswa. Metode penelitian menggunakan Penelitian Tindakan Kelas. Pengumpulan data dilakukan melalui observasi, dokumentasi dan tes. Analisis data dilakukan dengan 3 (tiga) tahapan meliputi: reduksi data, penyajian data dan penarikan kesimpulan atau verifikasi. Hipotesis menyatakan diduga melalui penerapan metode Problem Based Learning (PBL) dapat meningkatkan prestasi belajar Bahasa Indonesia materi memahami iklan baris pada siswa kelas IX D SMP Negeri 6 Sukoharjo semester I Tahun Pelajaran 2017/2018. Dari data empirik menyatakan melalui penerapan metode Problem Based Learning (PBL) dapat meningkatkan prestasi belajar Bahasa Indonesia materi memahami iklan dari kondisi awal nilai rata-rata 70 dengan ketuntasan 54,54\% ke kondisi akhir pada siklus II nilai rata-rata 85 dengan ketuntasan 86, 36\% pada siswa kelas IX D SMP Negeri 6 Sukoharjo semester I Tahun Pelajaran 2017/2018. Sehingga dapat disimpulkan bahwa melalui penerapan metode Problem Based Learning (PBL) dapat meningkatkan prestasi belajar Bahasa Indonesia materi memahami iklan baris pada siswa kelas IX D SMP Negeri 6 Sukoharjo semester I Tahun Pelajaran 2017/2018.
\end{abstract}

Kata Kunci: prestasi belajar, bahasa Indonesia, iklan baris, problem based learning $(P B L)$

\begin{abstract}
This study aims to improve the learning achievement of Indonesian material understanding of classified ads in grade IX students of SMP Negeri 6 Sukoharjo in the first semester of Lesson 2017/2018 through the implementation of Problem Based Learning (PBL) method. This study uses a classroom action research conducted in 2 (two) cycles, conducted in SMP Negeri 6 Sukoharjo with the subject of the study of all students of class IX D Junior High School 6 Sukoharjo first semester of 2017/2018 Lesson Year which amounted to 22 students. Research method using Classroom Action Research. Data collection is done through observation, documentation and test. Data analysis was done with 3 (three) stages including: data reduction, data presentation and conclusion or verification. Hypothesis states allegedly through the application of Problem Based Learning (PBL) method can improve learning achievement Indonesian language material
\end{abstract}


understand classified ads on students of class IX D Junior High School 6 Sukoharjo first semester Lesson 2017/2018. From the empirical data states through the application of Problem Based Learning (PBL) method can improve learning achievement Indonesian material understand the ads from the initial condition of the average value of 70 with the completeness of $54.54 \%$ to the final condition in cycle II average value 85 with completeness $86,36 \%$ in grade IX students of SMP Negeri 6 Sukoharjo in the first semester of Lesson 2017/2018. So it can be concluded that through the application of Problem Based Learning (PBL) method can improve learning achievement Indonesian language comprehension material classified ads on students of class IX D Junior High School 6 Sukoharjo first semester Lesson 2017/2018.

Keywords: learning achievement, Indonesian language, classified ads, problem based learning $(P B L)$

\section{PENDAHULUAN}

Bangsa Indonesia sebenarnya salah satu bangsa yang memiliki ciri khas bahasa resmi negara yang unik yang sama dengan nama negaranya, yaitu Bahasa Indonesia. Bahasa Indonesia menjadi bahasa persatuan dari Negara Kesatuan Republik Indonesia (NKRI) yang terdiri dari berbagai suku, agama, ras, termasuk bahasa daerahnya. Di tengah-tengah perbedaan bahasa inilah Bahasa Indonesia hadir sebagai bahasa persatuan. Pelajaran Bahasa Indonesia sebagai salah satu mata pelajaran yang wajib diikuti oleh siswa di sekolah pada jenjang pendidikan dasar dan menengah dipandang sebagian siswa sebagai mata pelajaran yang sulit dan kurang diminati. Padahal siswa seharusnya menyadari bahwa kemampuan memahami pelajaran Bahasa Indonesia terutama materi memahami iklan yang sangat dibutuhkan dalam menghadapi zaman yang semakin cepat, era persaingan global, sehingga kita mengetahui bagaimana pentingnya pengiklanan dalam memberitahu dan mempengaruhi khalayak ramai tentang suatu produk.

Cara belajar yang akan dialami oleh siswa sepenuhnya ditentukan oleh pertimbangan professional guru mengenai sifat, tujuan, materi, kemampuan awal siswa (entry behavior), sifat sumber materi dan suasana belajar. Jika seorang pendidik mampu menguasai dan menentukan metode belajar yang sesuai dengan kebutuhan siswa maka proses belajar mengajar di kelas akan berlangsung dengan baik. Hal tersebut juga akan berdampak baik terhadap prestasi belajar yang dicapai siswa (Djamarah, 2000:24). Dengan demikian peranan seorang pendidik (guru) dalam kegiatan belajar mengajar sangat penting, karena berhasil atau tidaknya kegiatan belajar mengajar tersebut sangat ditentukan oleh kreativitas guru dalam mengemas suatu mata pelajaran sehingga dapat menarik minat siswa untuk lebih mendalami dan mempelajari mata pelajaran tersebut.

Keberhasilan pembelajaran dipengaruhi oleh banyak faktor, diantaranya faktor minat, bakat, tingkat intelegensi, sikap, dan strategi pembelajaran. Pada pembelajaran Bahasa Indonesia, diperlukan strategi pembelajaran yang sesuai yang melibatkan siswa seoptimal mungkin baik secara intelektual maupun emosional. Oleh karena itu, guru 
dituntut untuk menguasai strategi-strategi penyampaian materi serta menguasai materi yang akan disampaikan.

Guru yang profesional akan selalu berupaya untuk meningkatkan pemahaman siswa terhadap materi yang diajarkan. Hal ini sejalan dengan tujuan pendidikan nasional yang dirinci sebagai berikut: 1) Mendidik adalah usaha sadar untuk meningkatkan dan menyiapkan peserta didik melalui kegiatan bimbingan, pengajaran dan atau latihan bagi perannya dimasa yang akan dating; 2) Peserta didik adalah anggota masyarakat yang berusaha mengembangkan din melalui proses pendidikan pada jalur dan jenjang pendidikan tertentu (Pribadi, 2009:42).

Dalam upaya meningkatkan proses belajar, guru harus berupaya menciptakan strategi yang cocok, sebab dalam proses belajar mengajar yang bermakna, keterlibatan siswa sangatlah penting, hal ini sesuai dengan pendapat Ilyas (2008: 12) yang menyebutkan bahwa kadar pembelajaran akan bermakna apabila: 1) Adanya keterlibatan siswa dalam proses belajar mengajar. 2) Adanya keterlibatan intelektual-emosional siswa baik melalui kegiatan menganalisa, berbuat dan pembentukan sikap. 3) Adanya keikutsertaan siswa secara kreatif dalam menciptakan situasi yang cocok untuk berlangsungnya proses belajar mengajar.

Keberhasilan dari suatu kegiatan sangat ditentukan oleh perencanaannya. Apabila perencanaan suatu kegiatan dirancang dengan baik, maka kegiatan akan lebih mudah dilaksanakan, terarah serta terkendali. Menurut Sagala (2008:6), perencanaan pembelajaran berperan sebagai acuan bagi guru untuk melaksanakan kegiatan pembelajaran agar lebih terarah dan berjalan efisien dan efektif. Dengan perkataan lain perencanaan pembelajaran berperan sebagai skenario proses pembelajaran. Oleh karena itu perencanaan pembelajaran hendaknya bersifat luwes (fleksibel) dan memberi kemungkinan bagi guru untuk menyesuaikannya dengan respon siswa dalam proses pembelajaran sesungguhnya.

Kegiatan mengajar merupakan upaya kegiatan menciptakan suasana yang mendorong inisiatif, motivasi dan tanggung jawab pada siswa untuk selalu menerapkan seluruh potensi diri dalam membangun gagasan melalui kegiatan belajar sepanjang hayat. Gagasan dan pengetahuan ini akan membentuk ketrampilan, sikap dan perilaku sehari-hari sehingga siswa akan berkompeten dalam bidang yang dipelajarinya. Ada kalanya dalam memberikan materi pelajaran kepada anak didik tidak selalu berjalan lancar sesuai dengan perencanaan atau gagal. Banyak faktor yang menyebabkan kegagalan dalam memberikan materi pelajaran. Dari faktor anak, tingkat intelegensi dan latar belakang anak didik yang berbeda-beda menyebabkan hasil pembelajaran yang tidak sama pula. Sedangkan penyebab lain dari pihak guru adalah cara penyampaian materi yang dianggap anak didik sulit memahaminya, kurangnya media pembelajaran, metode pembejaran yang salah, sehingga tujuan pembelajaran kepada anak didik tidak mengenai sasaran, dan masih banyak lagi sebab-sebab kegagalan siswa untuk mencapai tujuan pendidikan.

Prestasi belajar Bahasa Indonesia materi memahami iklan pada siswa kelas IX D SMP Negeri 6 Sukoharjo Kecamatan Sukoharjo, Kabupaten Sukoharjo Semester I Tahun Pelajaran 2017/2018 termasuk rendah. Dari data prestasi belajar Bahasa Indonesia materi memahami iklan kelas IX D, nilai rata-rata prestasi belajar siswa adalah 70, di bawah nilai 
Kriteria Ketuntasan Minimal (KKM) yang ditetapkan untuk mata pelajaran Bahasa Indonesia yaitu 75. Hanya 12 siswa $(54,54 \%)$ yang mencapai nilai KKM dari total 22 siswa kelas IX D. Sedangkan 10 siswa yang lain nilainya masih di bawah KKM. Hal ini menunjukan bahwa prestasi belajar Bahasa Indonesia materi memahami iklan siswa kelas IX D SMP Negeri 6 Sukoharjo semester I Tahun Pelajaran 2017/2018 masih rendah dan jauh dari yang diharapkan.

Observasi awal menunjukkan bahwa motivasi siswa masih rendah, siswa kurang aktif dalam kegiatan pembelajaran. Kesenjangan antara situasi dan kondisi pembelajaran di kelas IX D dan kondisi ideal pembelajaran Bahasa Indonesia materi memahami iklan menimbulkan beberapa masalah pembelajaran yang harus segera dicari solusinya agar prestasi siswanya semakin meningkat.

Selama ini guru dalam pembelajaran Bahasa Indonesia hanya menggunakan metode konvensional ceramah. Dalam pembelajaran ini guru yang aktif menyampaikan materi pelajaran, sedangkan siswa hanya pasif mendengarkan. Padahal dalam pelajaran Bahasa Indonesia materi memahami iklan, siswa perlu mendapatkan gambaran yang lebih konkrit sehingga lebih mudah memahami materi pelajaran dan dapat meningkat prestasi belajarnya. Untuk mengatasi kesulitan dalam pembelajaran ini, maka peneliti merasa perlu untuk menerapkan metode pembelajaran yang sesuai, metode yang menuntut siswa kelas IX D untuk menemukan konsep pembelajaran secara utuh. Dalam penelitian tindakan kelas ini peneliti akan menerapkan problem based learning (PBL).

Menurut Sriyono (1992:118), "Metode pemecahan masalah adalah suatu cara pembelajaran dengan menghadapkan siswa kepada sesuatu masalah dipecahkan atau diselesaikan", dengan demikian metode pemecahan masalah mendorong dan memberikan kesempatan seluas-luasnya kepada siswa untuk berinisiatip dan berfikir sistematis dalam menghadapi suatu masalah pada penerapannya. Metode ini cenderung akan lebih banyak menggunakan pendekatan belajar secara kelompok. Dengan ini diharapkan melalui sosialisasi yang dilakukan dalam kelompok siswa berlatih bekerja sama, berkoordinasi, saling tukar pikiran, dan mengembangkan komunikasi yang baik kepada guru maupun sesama rekan-rekannya.

\section{KAJIAN TEORI Iklan}

Iklan adalah sebuah informasi yang tujuannya untuk mendorong, membujuk/memberikan pengaruh kepada khalayak ramai atau banyak orang agar tertarik pada barang/jasa yang ditawarkan. Iklan adalah sebuah pengumuman yang berisi informasi produk dan di sebarkan kepada khalayak ramai. Dalam melakukan pengiklanan tentunya memiliki tujuan, tujuan iklan antara lain adalah sebagai berikut: a) Memberitahukan kepada khalayak ramai tentang suatu produk. b) Mempengaruhi khalayak ramai tentang suatu produk. c) Menyarankan seseorang untuk membeli suatu produk yang di iklankan. d) Memberikan informasi tentang produk. e) Menarik khalayak ramai. f) Dan lain-lain.

Secara umum iklan di tujukan kepada khalayak ramai, dan harus sesuai antara target pasar dengan produk yang ingin di tawarkan. Misalnya, jika ingin mengiklankan sebuah 
produk kendaraan, maka target orang yang akan melihat iklan tersebut adalah orang kalangan atas atau orang yang membutuhkan kendaraan.

Dalam melakukan pengiklanan tentunya memiliki syarat-syarat yang harus dilakukan. Syarat iklan dari segi isi iklan antara lain: a) Harus objektif dan jujur. b) Singkat, jelas dan mudah dipahami. c) Tidak menyinggung pihak lain. d) Menarik perhatian orang banyak. Selain syarat iklan dari segi isi iklan itu sendiri dalam melakukan pengiklanan juga harus memenuhi syarat dari segi bahasa. Syarat iklan dari segi bahasa iklan antara lain: a) Menggunakan pilihan kata yang tepat, menarik, logis dan sopan. b) Ungkapan/majas yang digunakan memikat dan memiliki daya sugesti bagi khalayak. c) Bahasa disusun untuk menonjolkan informasi yang dipentingkan. d) Teks iklan harus menuju sasaran.

Jenis-jenis Iklan. a) Iklan pemberitahuan/pengumuman. Iklan yang bertujuan untuk memberitahukan sesuatu kepada khalayak. Salah satu contoh iklan pemberitahuan adalah iklan keluarga. contoh : kelahiran, ulang tahun, perkawinan, kematian, dan sebagainya. b) Iklan undangan. Iklan yang berisi ajakan atau berupa himbauan untuk mendatangi suatu acara atau sesuatu kegiatan yang sudah dirancang sebelumnya.

\section{Problem Based Learning (PBL)}

Menurut Marpaung (2002) paradigma belajar memiliki ciri-ciri sebagai berikut: 1) Pengetahuan itu dianggap kontruksi dari mereka yang belajar dibentuk oleh pengalaman individual. 2) Siswa harus aktif mengolah informasi dengan berbagai cara, misalnya melalui interaksi dengan sesama siswa atau dengan guru. 3) Pengetahuan tidak ditransfer dari pikiran seseorang ke pikiran orang lain. 4) Guru mengalami perbedaan individual dan berusaha mengembangkan kemampuan siswa tersebut mengikuti alur proses kognitif siswa. 5) Lingkungan belajar dan belajar itu sendiri bersifat komperatif, koloboratif dan suportif. 6) Menghendaki siswa yang aktif, bukannya guru yang aktif.

Dalam paradigma belajar, peran guru sebagai fasilitator atau pembimbing belajar. Pembelajaran adalah membimbing atau men-dorong siswa aktif mengolah informasi, mendorong siswa berani mengutarakan ide-idenya, mau belajar dari kesalahan, berdiskusi dengan siswa lain dan guru. Melalui paradigma belajar, siswa memiliki kesempatan lebih besar mengembangkan dirinya menjadi manusia yang lebih mandiri, demokratis, berfikir variatif dan bersikap kritis.

Berbeda dengan metode konvensional yang menempatkan siswa sebagai pendengar setia dari apa yang disampaikan guru, metode pemecahan masalah menempatkan siswa sebagai subjek utama, yang secara aktif ikut ambil bagian dalam proses pembelajaran, khususnya untuk memecahkan masalah-masalah yang disodorkan guru kepada siswa, keberadaan guru hanyalah sebagai fasilitator proses belajar siswa yang membantu menciptakan kondisi yang memungkinkan siswa belajar dengan baik (Mujiono, 1999: 138).

Menurut Sriyono (1992: 118), "Metode pemecahan masalah adalah suatu cara pembelajaran dengan menghadapkan siswa kepada sesuatu masalah dipecahkan atau diselesaikan", dengan demikian metode pemecahan masalah mendorong dan memberikan 
kesempatan seluas-luasnya kepada siswa untuk berinisiatip dan berfikir sistematis dalam menghadapi suatu masalah pada penerapannya.

Metode ini cenderung akan lebih banyak menggunakan pendekatan belajar secara kelompok. Dengan ini diharapkan melalui sosialisasi yang dilakukan dalam kelompok siswa berlatih bekerja sama, berkoordinasi, saling tukar pikiran, dan mengembangkan komunikasi yang baik kepada guru maupun sesama rekan-rekannya.

\section{Bahasa Indonesia}

Pengertian bahasa telah banyak didefinisikan oleh para ahli menurut pandangan mereka masing-masing. Menurut Santoso, bahasa adalah rangkaian bunyi yang dihasilkan oleh alat ucap manusia secara sadar. Menurut Mackey, bahasa adalah suatu bentuk dan bukan suatu keadaan atau juga suatu sistem dari sekian banyak sistem-sistem, suatu sistem dari suatu tatanan atau suatu tatanan dalam sistem-sistem. Menurut Wibowo, bahasa adalah sistem simbol bunyi yang bermakna dan berartikulasi yang dipakai sebagai alat berkomunikasi oleh sekelompok manusia untuk melahirkan perasaan dan pikiran. Walija mengungkapkan definisi bahasa ialah komunikasi yang paling lengkap dan efektif untuk menyampaikan ide, pesan, maksud, perasaan dan pendapat kepada orang lain. Pengabean berpendapat bahwa bahasa adalah suatu sistem yang mengutarakan dan melaporkan apa yang terjadi pada sistem saraf. Menurut Kerafsm Arapradhipa memberikan pendapat bahwa Bahasa itu Sebagai alat komunikasi antara anggota masyarakat berupa simbol bunyi yang dihasilkan oleh alat ucap manusia atau sistem komunikasi yang mempergunakan simbol-simbol vokal. Menurut Torigan bahasa adalah suatu sistem yang sistematis barangkali untuk sistem generatif atau seperangkat lambang-lambang atau simbol-simbol orbiter.

Dengan demikian maka bahasa adalah suatu sistem dari lambang bunyi arbitrer yang dihasilkan oleh alat ucap manusia dan dipakai oleh masyarakat komunikasi, kerja sama dan identifikasi diri. Bahasa lisan merupakan bahasa primer, sedangkan bahasa tulisan adalah bahasa sekunder. Arbitrer yaitu tidak adanya hubungan antara lambang bunyi dengan bendanya. Bahasa Indonesia adalah bahasa yang menjadi wahana komunikasi dan alat ekspresi budaya yang mencerminkan eksistensi bangsa Indonesia. Pengembangan sikap berbahasa yang mencakup kemahiran berbahasa Indonesia dalam wadah pendidikan formal (sekolah) dilaksanakan melalui mata pelajaran atau mata kuliah Bahasa Indonesia.

\section{Bahasa Indonesia}

Pengertian bahasa telah banyak didefinisikan oleh para ahli menurut pandangan mereka masing-masing. Menurut Santoso, bahasa adalah rangkaian bunyi yang dihasilkan oleh alat ucap manusia secara sadar. Menurut Mackey, bahasa adalah suatu bentuk dan bukan suatu keadaan atau juga suatu sistem dari sekian banyak sistem-sistem, suatu sistem dari suatu tatanan atau suatu tatanan dalam sistem-sistem. Menurut Wibowo, bahasa adalah sistem simbol bunyi yang bermakna dan berartikulasi yang dipakai sebagai alat berkomunikasi oleh sekelompok manusia untuk melahirkan perasaan dan pikiran. Walija mengungkapkan definisi bahasa ialah komunikasi yang paling lengkap dan efektif untuk 
menyampaikan ide, pesan, maksud, perasaan dan pendapat kepada orang lain. Pengabean berpendapat bahwa bahasa adalah suatu sistem yang mengutarakan dan melaporkan apa yang terjadi pada sistem saraf. Menurut Kerafsm Arapradhipa memberikan pendapat bahwa Bahasa itu Sebagai alat komunikasi antara anggota masyarakat berupa simbol bunyi yang dihasilkan oleh alat ucap manusia atau sistem komunikasi yang mempergunakan simbol-simbol vokal. Menurut Torigan bahasa adalah suatu sistem yang sistematis barangkali untuk sistem generatif atau seperangkat lambang-lambang atau simbol-simbol orbiter.

Dengan demikian maka bahasa adalah suatu sistem dari lambang bunyi arbitrer yang dihasilkan oleh alat ucap manusia dan dipakai oleh masyarakat komunikasi, kerja sama dan identifikasi diri. Bahasa lisan merupakan bahasa primer, sedangkan bahasa tulisan adalah bahasa sekunder. Arbitrer yaitu tidak adanya hubungan antara lambang bunyi dengan bendanya. Bahasa Indonesia adalah bahasa yang menjadi wahana komunikasi dan alat ekspresi budaya yang mencerminkan eksistensi bangsa Indonesia. Pengembangan sikap berbahasa yang mencakup kemahiran berbahasa Indonesia dalam wadah pendidikan formal (sekolah) dilaksanakan melalui mata pelajaran atau mata kuliah Bahasa Indonesia.

Bahasa dibentuk oleh kaidah aturan serta pola yang tidak boleh dilanggar agar tidak menyebabkan gangguan pada komunikasi yang terjadi. Kaidah, aturan dan pola-pola yang dibentuk mencakup tata bunyi, tata bentuk dan tata kalimat. Agar komunikasi yang dilakukan berjalan lancar dengan baik, penerima dan pengirim bahasa harus harus menguasai bahasanya.

Bahasa adalah suatu sistem dari lambang bunyi arbitrer yang dihasilkan oleh alat ucap manusia dan dipakai oleh masyarakat komunikasi, kerja sama dan identifikasi diri. Bahasa lisan merupakan bahasa primer, sedangkan bahasa tulisan adalah bahasa sekunder. Arbitrer yaitu tidak adanya hubungan antara lambang bunyi dengan bendanya.

\section{Fungsi Bahasa Indonesia}

a) Fungsi bahasa (umum)

Alat ekspresi diri: Bahasa sebagai alat ekspresi diri berarti dengan bahasa manusia dapat menyatukan secara terbuka segala sesuatu yang tersirat di dalam pikiran manusia untuk mengekspresikan diri. Alat komunikasi: Bahasa merupakan saluran yang memungkinkan untuk bekerja sama dengan sesama manusia. Bahasa sebagai alat komunikasi memungkinkan setiap orang untuk merasa dirinya terikat dengan kelompok sosial tertentu, dan dapat melakukan semua kegiatan kemasyarakatan serta memungkinkan integrasi (pembauran). Alat integrasi dan adaptasi sosial: Bahasa sebagai alat integrasi, bahasa memungkinkan setiap penuturannya merasa diri terikat dalam kelompok sosial atau masyarakat yang menggunakan bahasa yang sama, para anggota kelompok itu dapat melakukan kerja sama dan membentuk masyarakat. Bahasa yang sama yang memungkinkan mereka bersatu atau berintegrasi di dalam masyarakat tersebut. Sebagai alat kontrol sosial: Bahasa dapat digunakan untuk mengatur berbagai aktivitas sosial, merencanakan berbagai kegiatan, dan mengarahkan kedalam suatu 
tujuan yang di inginkan. Bahasa pula yang dilakukan oleh seseorang. Segala kegiatan atau aktivitas dapat berjalan dengan baik apabila diatur atau dikontrol dengan bahasa.

Menurut Keraf (1984:6) proses sosialisasi dapat dilakukan dengan cara: mempunyai keahlian bicara, membaca dan menulis; bahasa saluran utama dalam memberikan kepercayaan kepada anak-anak yang sedang tumbuh; bahasa menjelaskan dan melukiskan perasaan anak untuk mengidentifikasi dirinya, supaya dapat mengambil tindakan-tindakan yang di perlukan; dan bahasa menawarkan dasar keterlibatan pada si anak tentang masyarakat bahasanya.

b) Fungsi bahasa ( khusus)

Fungsi bahasa khusus di sini antara lain: bahasa resmi kenegaraan; bahasa pengantar dalam dunia pendidikan; dan bahasa resmi untuk kepentingan perencanaan pembangunan. Di dalam kedudukannya sebagai bahasa nasional, bahasa Indonesia berfungsi sebagai: lambang kebangsaan; lambang identitas nasional; alat penghubung antarwarga, antardaerah dan antarbudaya; dan alat yang memungkinkan penyatuan berbagai suku bangsa dengan latar belakang sosial budaya dan bahasa yang berbedabeda ke dalam satu kesatuan kebangsaan yang bulat. Di dalam kedudukannya sebagai bahasa negara, bahasa indonesia berfungsi sebagai: bahasa resmi kenegaraan; bahasa pengantar di dalam dunia pendidikan; alat perhubungan pada tingkat nasional untuk kepentingan perencanaan dan pelaksanaan pembangunan; dan alat pengembangan kebudayaan, ilmu pengetahuan dan teknologi.

\section{Kedudukan Bahasa Indonesia}

a) Sebagai Bahasa Nasional

Seperti yang tercantum dalam ikrar ketiga Sumpah Pemuda 1928 yang berbunyiKami putra dan putri Indonesia menjunjung bahasa persatuan, bahasa Indonesia.Ini berarti bahasa Indonesia berkedudukan sebagai bahasa Nasional yang kedudukannya berada diatas bahasa-bahasa daerah.

b) Sebagai Bahasa Negara

Tercantum dalam Undang-Undang Dasar 1945 (Bab XV Pasal 36) mengenasi kedudukan bahasa Indonesia yang menyatakan bahawa bahasa negara ialah bahasa Indonesia. Bahasa Indonesia memiliki kedudukan yang sangat penting seperti yang tercantum dalam: Ikrar ketiga Sumpah Pemuda 1928 dengan bunyi, "Kami putra dan putri Indonesia menjunjung bahasa persatuan, bahasa Indonesia. Undang-Undang Dasar RI 1945 Bab XV (Bendera, Bahasa, dan Lambang Negara, serta Lagu Kebangsaan) Pasal 36 menyatakan bahwa "Bahasa Negara ialah Bahasa Indonesia". Dari Kedua hal tersebut, maka kedudukan bahasa Indonesia sebagai: Bahasa kebangsaan, kedudukannya berada di atas bahasa-bahasa daerah dan Bahasa negara (bahasa resmi Negara Kesatuan Republik Indonesia).

\section{Hakikat Belajar}

Belajar adalah proses perubahan perilaku berkat pengalaman dan latihan. Hamalik (2007: 6-17) mengemukakan bahwa setiap proses belajar selalu berlangsung dalam tiga 
tahapan sebagai berikut: a) Acquation (tahap perolehan atau penerimaan informasi). Pada tingkatan ini seorang siswa mulai menerima informasi sebagai stimulus dan melakukan respon terhadapnya, sehingga menimbulkan pemahaman dan aktivitas baru. b) Strorage (tahap menyimpan informasi). Pada tingkatan ini seorang siswa akan mengaktifkan fungsifungsi memorinya, misalnya ketika ia menjawab pertanyaan atau memecahkan masalah. Proses retrieval pada dasarnya adalah upaya atau peristiwa mental dalam mengungkapkan dan mereduksi kembali apa yang tersimpan dalam materi. c) Retrieval (tahap mendapatkan kembali informasi). Pada tingkatan ini seseorang siswa akan mengaktifkan fungsi-fungsi memorinya, misalnya ketika ia menjawab pertanyaan atau memecahkan masalah. Pross retrieval pada dasarnya adalah upaya atau peristiwa mental dalam mengungkapkan dan memproduksi kembali apa yang tersimpan dalam memori.

Menurut Dimyati dan Mudjiono (2006:156), belajar adalah proses melibatkan manusia secara orang per orang sebagai satu kesatuan organisme sehingga terjadi perubahan pada pengetahuan, keterampilan, dan sikap. Hakikat belajar adalah perubahan dalam tingkah laku si subyek dalam situasi tertentu berkat pengalamannya yang berulangulang, dan perubahan tingkah laku tersebut tidak dapat dijelaskan atas dasar kecenderungan respon bawaan, kematangan atau keadaan temporer dari subjek ( Hilgard dan Gordon, dalam Suyahman, 2006:3).

Dari berbagai pengertian di atas, belajar pada hakekatnya adalah perubahan tingkah laku dari seseorang yang menyangkut pengetahuan, ketrampilan dan sikap. Belajar merupakan peningkatan kemampuan kognitif, afektif dan psikomotorik menjadi lebih baik

Belajar merupakan proses penting bagi perubahan perilaku pada diri seseorang dan mencakup segala sesuatu yang dipikirkan dan dikerjakan. Belajar memegang peranan penting di dalam perkembangan, kebiasaan, sikap, keyakinan, tujuan, kepribadian, dan bahkan persepsi manusia. Di dalam belajar terdapat prinsip-prinsip belajar yang harus diperhatikan, Dalyono (2005: 51-54).

Salah satu indikator tercapai atau tidaknya suatu proses pembelajaran adalah dengan melihat prestasi belajar yang dicapai oleh siswa. Poerwanto (1986:28), memberikan pengertian prestasi belajar yaitu "hasil yang dicapai oleh seseorang dalam usaha belajar sebagaimana yang dinyatakan dalam raport." Winkel (1996:226) mengemukakan bahwa prestasi belajar merupakan bukti keberhasilan yang telah dicapai oleh seseorang. Maka prestasi belajar merupakan hasil maksimum yang dicapai oleh seseorang setelah melaksanakan usaha-usaha belajar.

Sedangkan menurut Arif Gunarso (1993: 77), mengemukakan bahwa prestasi belajar adalah usaha maksimal yang dicapai oleh seseorang setelah melaksanakan usaha-usaha belajar. S.Nasution (1996: 17), prestasi belajar adalah: "Kesempurnaan yang dicapai seseorang dalam berpikir, merasa dan berbuat. Prestasi belajar dikatakan sempurna apabila memenuhi tiga aspek yakni: kognitif, affektif dan psikomotor, sebaliknya dikatakan prestasi kurang memuaskan jika seseorang belum mampu memenuhi target dalam ketiga criteria tersebut." Hasil belajar akan semakin maksimal jika semua unsur masyarakat menyadari pentingnya pendidikan, karena pendidikan cara perbaik memperbarui kualitas bangsa (Tho'in, 2017). 
Prestasi belajar di bidang pendidikan adalah hasil dari pengukuran terhadap peserta didik yang meliputi faktor kognitif, afektif dan psikomotor setelah mengikuti proses pembelajaran yang diukur dengan menggunakan instrumen tes atau instrumen yang relevan. Jadi prestasi belajar adalah hasil pengukuran dari penilaian usaha belajar yang dinyatakan dalam bentuk simbol, huruf maupun kalimat yang menceritakan hasil yang sudah dicapai oleh setiap anak pada periode tertentu. Prestasi belajar merupakan hasil dari pengukuran terhadap peserta didik yang meliputi faktor kognitif, afektif dan psikomotor setelah mengikuti proses pembelajaran yang diukur dengan menggunakan instrumen tes yang relevan.

Secara psikologis, belajar merupakan suatu proses perubahan tingkah laku sebagai hasil interaksi dengan lingkungan dalam memenuhi kebutuhan hidupnya. Perubahanperubahan itu akan nyata dari seluruh aspek tingkah lakunya. Belajar adalah suatu proses usaha yang dilakukan seseorang untuk memperoleh suatu perubahan tingkah laku yang baru secara keseluruhan, sebagai hasil pengalamannya sendiri dalam interaksi dengan lingkungannya.

\section{METODE}

Penelitian ini menggunakan bentuk penelitian tindakan kelas yang dilaksanakan dalam 2 (dua) siklus, dilaksanakan di SMP Negeri 6 Sukoharjo dengan subjek penelitian seluruh siswa kelas IX D SMP Negeri 6 Sukoharjo semester I Tahun Pelajaran 2017/2018 yang berjumlah 22 siswa. Metode penelitian menggunakan Penelitian Tindakan Kelas. Pengumpulan data dilakukan melalui observasi, dokumentasi dan tes. Analisis data dilakukan dengan 3 (tiga) tahapan meliputi: reduksi data, penyajian data dan penarikan kesimpulan atau verifikasi.

\section{PEMBAHASAN}

Setelah peneliti melaksanakan tindakan penelitian melalui penerapan metode Problem Based Learning (PBL), secara empiris diperoleh data peningkatan prestasi belajar Bahasa Indonesia materi memahami iklan pada siswa kelas IX D SMP Negeri 6 Sukoharjo Kecamatan Sukoharjo, Kabupaten Sukoharjo semester I Tahun Pelajaran 2017/2018 dari kondisi awal, siklus I dan siklus II sebagai berikut.

Tabel 1. Peningkatan Prestasi Belajar Siswa

\begin{tabular}{|l|c|c|c|}
\hline \multicolumn{1}{|c|}{ Uraian } & Kondisi awal & Siklus I & Siklus II \\
\hline Tindakan & $\begin{array}{c}\text { Belum menerapkan } \\
\text { metode Problem } \\
\text { Based Learning } \\
(P B L) .\end{array}$ & $\begin{array}{c}\text { Sudah menerapkan } \\
\text { metode Problem } \\
\text { Based Learning } \\
(P B L)\end{array}$ & $\begin{array}{c}\text { Sudah menerapkan } \\
\text { metode Problem Based } \\
\text { Learning }(P B L)\end{array}$ \\
\hline Nilai terendah & 60 & 65 & 70 \\
Nilai tertinggi & 80 & 90 & 90 \\
Nilai rata-rata & 70 & 75 & 85 \\
KKM & 75 & 75 & 75 \\
Ketuntasan & 12 siswa $(54,54 \%)$ & 14 siswa $(63,63 \%)$ & 19 siswa $(86,36 \%)$ \\
\hline
\end{tabular}


Melalui penerapan metode Problem Based Learning (PBL) dapat meningkatkan prestasi belajar Bahasa Indonesia materi memahami iklan. Pada kondisi awal peneliti belum menerapkan metode Problem Based Learning (PBL). Nilai rata-rata siswa kelas IX D adalah 70, masih di bawah nilai KKM yang ditetapkan yaitu 75. Nilai tertinggi siswa 80, nilai terendah 60 dan jumlah siswa kelas IX D yang mencapai nilai KKM hanya 12 siswa $(54,54 \%)$ dari total 22 siswa kelas IX D SMP Negeri 6 Sukoharjo.

Pada siklus I guru peneliti sudah menerapkan metode Problem Based Learning (PBL) dalam pembelajaran Bahasa Indonesia materi memahami iklan. Nilai rata-rata prestasi belajar Bahasa Indonesia materi memahami iklan siswa kelas IX D SMP Negeri 6 Sukoharjo adalah 75, nilai tertinggi 90 dan nilai terendah adalah 65. Sedangkan jumlah siswa yang mencapai nilai KKM sebanyak 14 siswa $(63,63 \%)$ dari total 22 siswa kelas IX D SMP Negeri 6 Sukoharjo.

Pada siklus II, nilai rata-rata prestasi belajar Bahasa Indonesia materi memahami iklan 22 siswa kelas IX D SMP Negeri 6 Sukoharjo adalah 85, nilai tertinggi 90 dan nilai terendah 70. Jumlah siswa yang mencapai nilai KKM sebanyak 19 siswa $(86,36 \%)$ dari total 22 siswa kelas IX D SMP Negeri 6 Sukoharjo.

Jadi, melalui penerapan metode Problem Based Learning (PBL) dapat meningkatkan prestasi belajar Bahasa Indonesia materi memahami iklan dari kondisi awal nilai rata-rata 70 dengan ketuntasan 54, 54\% ke kondisi akhir pada siklus II nilai rata-rata 85 dengan ketuntasan 86, 36\% pada siswa kelas IX D SMP Negeri 6 Sukoharjo semester I Tahun Pelajaran 2017/2018.

Hasil tindakan secara empirik yaitu: melalui penerapan metode Problem Based Learning (PBL) dapat meningkatkan prestasi belajar Bahasa Indonesia materi memahami iklan dari kondisi awal nilai rata-rata 70 dengan ketuntasan $54,54 \%$ ke kondisi akhir pada siklus II nilai rata-rata 85 dengan ketuntasan $86,36 \%$ pada siswa kelas IX D SMP Negeri 6 Sukoharjo semester I Tahun Pelajaran 2017/2018.

\section{SIMPULAN}

Hipotesis menyatakan diduga melalui penerapan metode Problem Based Learning $(P B L)$ dapat meningkatkan prestasi belajar Bahasa Indonesia materi memahami iklan pada siswa kelas IX D SMP Negeri 6 Sukoharjo semester I Tahun Pelajaran 2017/2018. Dari data empirik menyatakan melalui penerapan metode Problem Based Learning (PBL) dapat meningkatkan prestasi belajar Bahasa Indonesia materi memahami iklan dari kondisi awal nilai rata-rata 70 dengan ketuntasan $54,54 \%$ ke kondisi akhir pada siklus II nilai rata-rata 85 dengan ketuntasan 86, 36\% pada siswa kelas IX D SMP Negeri 6 Sukoharjo semester I Tahun Pelajaran 2017/2018. Sehingga dapat disimpulkan bahwa melalui penerapan metode Problem Based Learning (PBL) dapat meningkatkan prestasi belajar Bahasa Indonesia materi memahami iklan pada siswa kelas IX D SMP Negeri 6 Sukoharjo semester I Tahun Pelajaran 2017/2018. 
Tri Indyastuti / Edunomika Vol. 02 No. 01 (Pebruari 2018)

\section{DAFTAR PUSTAKA}

Dalyono. 2005. Prestasi Belajar. Jakarta: Rineka Cipta.

Dimyati dan Mudjiono. 2002. Belajar dan Pembelajaran. Jakarta: Penerbit Rineka Cipta

Djamarah, Syaiful Bahri. 2000. Strategi Belajar Mengajar. Jakarta: PT. Rineka Cipta.

Gunarso, Arif. 1993. Bagaimana Bimbingan dan Penyuluhan Belajar di Sekolah. Surabaya: Usaha Nasional.

Hamalik, Oemar. 2005. Proses Belajar mengajar. Bumi Aksara. Jakarta.

Ilyas, T. 2008. Fungsi dan Pengukuran Prestasi Belajar. Yogyakarta: Pustaka Pelajar.

Keraf, Gorys. 1984. Diksi dan Gaya Bahasa. Jakarta: PT. Gramedia Pustaka

Marpaung, H. (2002). Pengetahuan Kepariwisataan. Bandung: Alfabeta.

Nasution S. 1990. Pengertian Belajar. Bandung : Bumi Aksara.

Poerwanto, Ngalim. 1986. Prinsip-prinsip dan Tehnik Evaluasi Pengajaran. Bandung: Remaja Karya

Pribadi, Benny A. 2009. Model Desain Sistem Pembelajaran. Jakarta: Dian Rakyat

Sagala, Saiful. 2008. Konsep dan Makna Pembelajaran Untuk Membantu Memecahkan Problematika Belajar dan Mengajar. Bandung: Alfabeta

Sriyono. (1992). Teknik Belajar Mengajar Dalam CBSA. Jakarta: Melton Putra.

Suyahman. 2006. Belajar dan Pembelajaran. Sukoharjo: Univet Bantara.

Undang-Undang Dasar 1945 (Bab XV Pasal 36)

Tho'in, M. (2017). Pembiayaan Pendidikan Melalui Sektor Zakat. Al-Amwal: Jurnal Ekonomi dan Perbankan Syari'ah, 9(2).

Winkel, W.S. 1996. Psikologi Pengajaran. Jakarta: Grasindo. 